\title{
Utilization of Chondroitin Sulfate as an Anhydrous Proton Conductor
}

\author{
Masanori Yamada* and Shunta Kawamura \\ Department of Chemistry, Faculty of Science, Okayama University of Science, Ridaicho, Kita-ku, \\ Okayama 700-0005, Japan \\ *E-mail: myamada@chem.ous.ac.jp
}

doi: $10.20964 / 2018.12 .21$

Received: 28 July 2018 / Accepted: 20 September 2018 / Published: 5 November 2018

Chondroitin sulfate C (CSC), one of the natural polysaccharides, is present in the connective tissue, brain, and cartilage. Therefore, the utilization of CSC has been limited to biological materials. In this study, we applied the CSC to the engineering field as a proton conducting material. The anhydrous proton conductive CSC-heterocycle composites were prepared by mixing the CSC material and the heterocycle imidazole (Im). The CSC-Im composite formed an acid-base composite by the electrostatic interaction between the acidic group, such as the carboxyl and sulfonic acid groups, and the nonprotonated $-\mathrm{N}=$ of the Im molecule and showed a thermal stability at $<200{ }^{\circ} \mathrm{C}$. Additionally, the anhydrous proton conductivity of the CSC-Im composite increased with the addition of the Im molecule and indicated the maximum value of $1.1 \times 10^{-3} \mathrm{~S} \mathrm{~cm}^{-1}$ at $130{ }^{\circ} \mathrm{C}$ under flowing dry-nitrogen. Furthermore, the activation energy $\left(E_{a}\right)$ of the proton conduction was $0.3-0.4 \mathrm{eV}$ and this $E_{a}$ value coincided with that of other anhydrous proton conductors. Therefore, the CSC-Im composite might be used as a novel anhydrous proton conductor.

Keywords: Chondroitin sulfate, Acid-base composite, Anhydrous proton conductor, Biopolymer, Polymer electrolyte

\section{$\underline{\text { FULL TEXT }}$}

(C) 2018 The Authors. Published by ESG (www.electrochemsci.org). This article is an open access article distributed under the terms and conditions of the Creative Commons Attribution license (http://creativecommons.org/licenses/by/4.0/). 